\title{
SOME DYNAMIC INEQUALITIES OF HARDY TYPE ON TIME SCALES
}

\section{S. H. SAKER, Donal O'REgAn And R. P. AgARwAL}

Abstract. In this paper we prove some new dynamic inequalities of Hardy type on time scales. The main results will be proved using algebraic inequalities, Hölder inequality and Keller's chain rule on time scales.

Mathematics subject classification (2010): 26A15, 26D10, 26D15, 39A13, 34A40, 34N05.

Keywords and phrases: Hardy's inequality, time scales.

\section{REFERENCES}

[1] P. R. Bessack, Hardy's inequality and its extensions, Pacific J. Math. 11 (1961), 39-61.

[2] M. Bohner And A. Peterson, Dynamic Equations on Time Scales: An Introduction with Applications, Birkhäuser, Boston, 2001.

[3] M. Bohner, A. Peterson, Advances in Dynamic Equations on Time Scales, Birkhäuser, Boston, 2003.

[4] L. Y. Chan, Some extensions of Hardy's inequality, Canadian Math. Bull. 22 (1979), 165-169.

[5] G. H. HARDY, Notes on a theorem of Hilbert, Math. Z. 6 (1920), 314-317.

[6] G. H. HARDY, Notes on some points in the integral calculus, Messenger Math. 57 (1928), 12-16.

[7] G. H. Hardy, J. E. Littlewood and G. Polya, Inequalities, 2nd Ed. Cambridge Univ. Press 1952.

[8] S. Hilger, Analysis on measure chains - a unified approach to continuous and discrete calculus, Results Math. 18 (1990) 18-56.

[9] M. Izumi And S. Izumi, On some inequlities for Fourier Series, J. D’Analyse Math. 21 (1968), 277-291.

[10] S. Kaijser, L. E. Persson And A. Öberg, On Carleman and Knopp's inequalities, J. Approx. Theor. 117 (2002), 140-151.

[11] A. Kufner And Lars-Erik Persson, Weighted Inequalities of Hardy Type, World Scientific Publishing (2003).

[12] A. Kufner, L. Maligranda and L. Persson, The Hardy inequalities: About its History and Some Related Results, Pilsen (2007).

[13] N. LeVInson, Generalizations of an inequality of hardy, Duke Math. J. 31 (1964), 389-394.

[14] J. A. Oguntuase And C. O. Imoru, New generalizations of Hardy's integral inequalties, J. Math. Anal. Appl. 241 (2000), 73-82.

[15] J. A. Oguntuase and E. O. Adeleke, On Hardy's integral inequality, Facta Univ. (NIS), Ser. MAth. Infor. 20 (2005), 9-20.

[16] B. OpIC AND A. KUfNer, Hardy-type inequalities, Longman Scientific\& Technical, Harlow, ESSex, UK, (1989).

[17] U. M. OzKan And H. YildiRim, Hardy-Knopp-type inequalities on time scales, Dyn. Sys. Appl. 17 (2008), 477-486.

[18] B. G. PAChPATte, A note on certain inequalities related to Hardy's inequality, Indian J. Pure Appl. Math 23 (1992), 773-776.

[19] B. G. Pachpatte, A note on some extensions of Hardy's inequality, Anales Stiniin. Ale Univ. “AL.I.CUZA" IASI, Tomul XLIV, s.I.a, Matematica (1998), 95-100. 
[20] P. ŘEHAK, Hardy inequality on time scales and its application to half-linear dynamic equations, J. Ineq. Appl. 2005: 5 (2005), 495-507.

[21] M. R. SIDI, A. F. M. TORRES, Hölder's and Hardy's two dimensional diamond-alpha inequalities on time scales, Annales of Univ. Craiva, Math. Comp. Series 37 (2010), 1-11.

[22] A. Tuna And S. Kutukcu, Some integrals inequalities on time scales, Appl. Math. Mech. Engl. Ed. 29 (2008), 23-29. 